\title{
Molecular assessment of Gymnotus spp. (Gymnotiformes: Gymnotidae) fishing used as live baitfish in the Tietê River, Brazil
}

\author{
Lilian Paula Faria-Pereira ${ }^{1}$, Alexandre Wagner Silva Hilsdorf ${ }^{2}$, James Albert ${ }^{3}$, \\ Maria José Tavares Ranzani Paiva ${ }^{4}$ and Márcia Santos Nunes Galvão ${ }^{5}$
}

\begin{abstract}
The capture of live bait for sport fishing is an important activity for fishing communities. The main species used for this purpose are members of the genus Gymnotus, which comprises numerous species of cryptic nature that are difficult to identify based on external morphology. The aims of this work were to identify through partial sequences of the COI gene Gymnotus species fished in the Jacaré-Guaçu River, SP, and to develop a molecular diagnostic approach using PCR-RFLP to identify these species. Partial COI sequences were compared to those of other species deposited in GenBank. The sequences were assessed in the NEBCutter program to determine restriction sites in the sequence and the enzymes to be tested. Phenetic analysis performed by Neighbor-Joining method showed that the specimens sampled belong to two species preliminary identified here as G. cf. sylvius and $G$. cf. cuia, with $G$. cf. sylvius accounting for $95.2 \%$ of the individuals sampled. The enzymes NlaIII and SacI generated fragments that allowed distinguishing the Gymnotus species using PCR-RFLP. This analysis can be used to accurately identify these species, which is fundamental for monitoring Gymnotus fishing and assessing the conservation of this genetic resource.
\end{abstract}

Keywords: Molecular identification, PCR-RFLP, Tuvira.

A captura de iscas-vivas para a pesca esportiva constitui uma atividade importante em comunidades de pescadores. As principais espécies utilizadas para este propósito pertencem ao gênero Gymnotus, o qual compreende inúmeras espécies de natureza críptica que dificulta a identificação baseada na morfologia externa. Os objetivos deste trabalho foram identificar através de sequências parciais do gene COI, espécies de Gymnotus capturadas no Rio Jacaré-Guaçu, Ibitinga, SP, e desenvolver um diagnóstico molecular por meio de PCR-RFLP. Sequências parciais de COI foram comparadas com outras espécies depositadas no GenBank. As sequências foram analisadas no Programa NebCutter para determinar os sítios de restrição e definir as enzimas a serem testadas. A análise fenética pelo método de Neighbor-Joining mostrou que os espécimes pertencem a duas espécies identificadas preliminarmente aqui como $G$. cf. sylvius e $G$. cf. cuia, sendo que $G$. cf. sylvius representou $95,2 \%$ dos indivíduos amostrados. As enzimas NlaIII e SacI geraram fragmentos que permitiram discriminar as espécies por meio de PCR-RFLP. Esta análise pode ser usada na identificação precisa destas espécies, fundamental na proposição de monitoramento da pesca de Gymnotus na região e para medidas adequadas de conservação.

Palavras-chave: Identificação molecular, PCR-RFLP, Tuvira.

\section{Introduction}

Species of Gymnotus Linnaeus, 1758 are an important fishing resource for fishermen communities and the principal source of commercial live bait for sport fishing (Sousa et al., 2017). The genus Gymnotus is a member of the family Gymnotidae (order Gymnotiformes). This genus consists of many species, represented by 43 valid species in six clades (Tagliacollo et al., 2016), with wide distribution in the continental waters of South and Central America, except in Chile and Belize (Albert, 2001).

The identification of species in this genus based on morphological characters is sometimes challenging due to the morphological conservatism among species

\footnotetext{
${ }^{1}$ Centro de Pesquisa e Desenvolvimento de Recursos Hídricos, Instituto de Pesca, Av. Francisco Matarazzo, 455, Perdizes, P.O. Box 61070, 05001-970 São Paulo, SP, Brazil. lilianpaula78@gmail.com (corresponding author), Ohttps://orcid.org/0000-0002-2950-1728

${ }^{2}$ Núcleo Integrado de Biotecnologia, Universidade de Mogi das Cruzes, P.O. Box 411, 08701-970 Mogi das Cruzes, SP, Brazil. wagner@umc.br, (1)https://orcid.org/0000-0001-9565-8072

${ }_{3}^{3}$ Department of Biology, University of Louisiana at Lafayette, PO Box 42451, Lafayette, LA, 70504, USA. jalbert@louisiana.edu, (Dhttps://orcid.org/0000-0001-5477-1749

${ }^{4}$ Centro de Pesquisa de Aquicultura, Instituto de Pesca, Av. Francisco Matarazzo, 455, Perdizes, P.O. Box 61070, 05001-970 São Paulo, SP, Brazil.mase@pesca.sp.gov.br, Ohttps://orcid.org/0000-0001-8279-047X

${ }_{5}^{5}$ Unidade de Pesquisa e Desenvolvimento de Pirassununga, Instituto de Pesca, Av. Virgilio Baggio, 85, Jardim Cachoeira, Pirassununga, 13641-004 São Paulo, SP, Brazil. margalvao@pesca.sp.gov.br, Ohttps://orcid.org/0000-0003-2467-4379
} 
and high phenotypic plasticity within species. Many efforts have been made based on studies of morphology, cytogenetics, molecular, and electrical signals to elucidate the taxonomy of electric fishes, including Gymnotus (Alves-Gomes et al., 1995; Albert, Crampton, 2003; Fernandes et al., 2005; Margarido et al., 2007; Maxime, Albert, 2009; Scacchetti et al., 2011; Milhomem et al., 2012; Tagliacollo et al., 2016; Sousa et al., 2017; Craig et al., 2017, 2018).

The existence of cryptic species in combination with poor-quality data from landing records for biomass estimation and catch quotas, may imperil the longterm survival of given fish genetic resources (Hilsdorf, Hallerman, 2017). In addition, worldwide concerns on the indiscriminate use of live baitfish, the ecological risks of introducing alien species, and the depletion of local species, are on the agenda of fish diversity conservation in many countries (Drake, Mandrak, 2014; Sousa et al., 2017). Therefore, the correct identification of species is one of the first steps towards successfully establishing conservation and management measures to protect local baitfish species. Hebert et al. (2003) proposed the use of a fragment of approximately $650 \mathrm{bp}$ of the mitochondrial cytochrome c oxidase subunit 1 (COI or COX1) as a global identification system for most animal species presently known as the DNA barcoding.
Supported by this background, we use partial sequences of COI to identify Gymnotus spp. captured as live baitfish and develop a rapid and low-cost molecular methodology to identify unequivocally the species being caught to help ensure the sustainability of Gymnotus fisheries and preserve the biodiversity of species.

\section{Material and Methods}

Collection and Sampling Site. Taxon sampling was carried out between October 2015 and March 2016 along the Jacaré-Guaçu River, a tributary of the Tietê River, southeast region of Brazil (Fig. 1). Eight individuals from four fishing sites were collected in two season periods, in a total of 64 individuals. All specimens were photographed, labeled and a small piece of muscle or fin clips were taken from each fresh fish and stored in $95 \%$ ethanol at $-20^{\circ} \mathrm{C}$. Voucher specimens were deposited in the Ichthyology Collection of the Museu de Zoologia da Universidade de São Paulo (MZUSP), SP, Brazil, receiving the register numbers MZUSP 124930 and MZUSP 124931.

The procedures carried out in this study were in accordance with the ethical standards of the Colégio Brasileiro de Experimentação Animal (COBEA) and were approved by the Comitê de Ética em Experimentação Animal do Instituto de Pesca (CEEAIP) protocol number 01/2016.

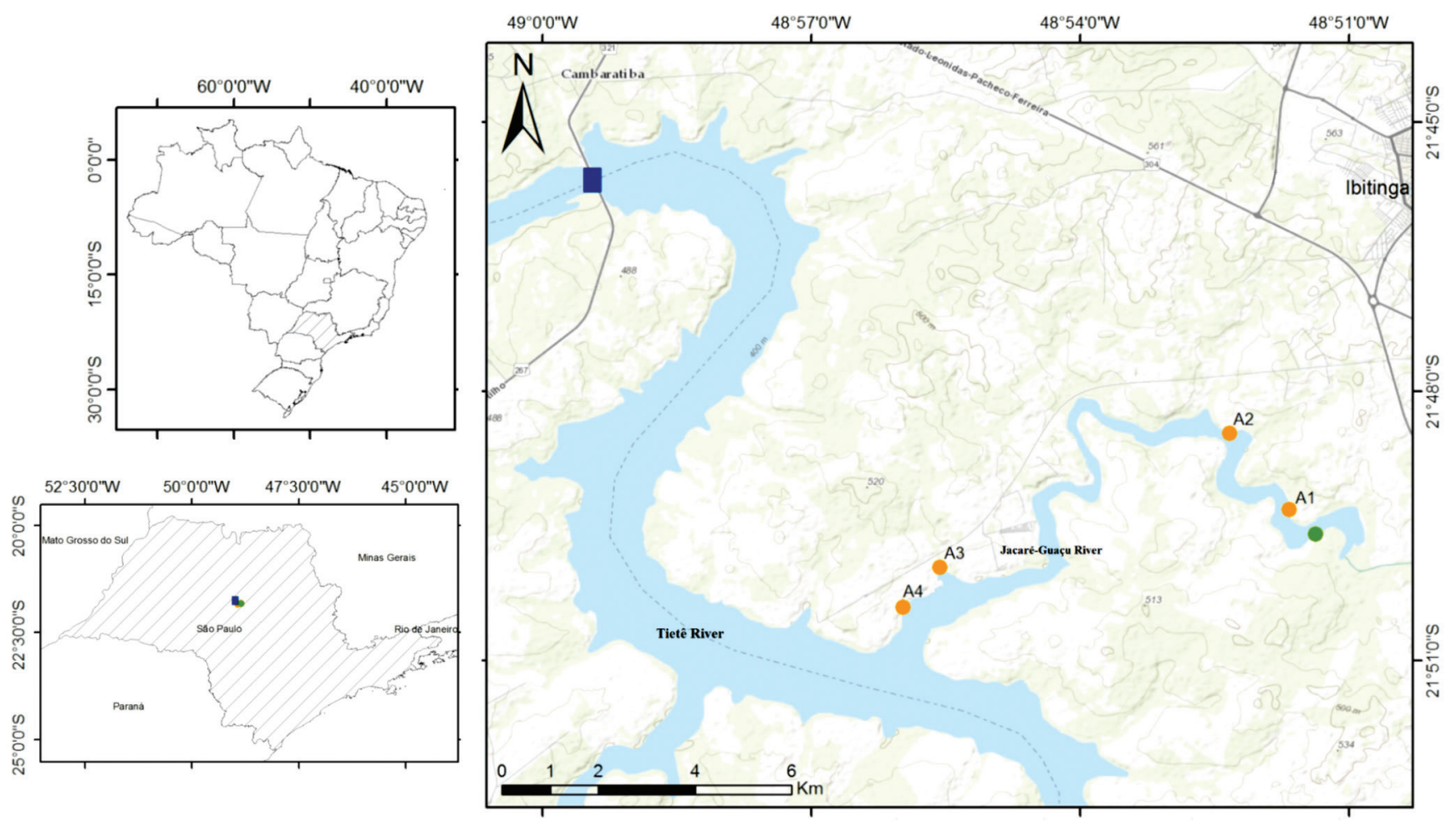

Fig. 1. Map of the study area. Characterization of the catchment sites of Gymnotus spp. in the Jacaré-Guaçu River, southeastern Brazil. Orange dots $(\mathrm{A} 1-\mathrm{A} 4)=$ collection sites; green dot $=$ embarkation and disembarkation; blue rectangle $=$ Ibitinga dam; lines on the diagonal = boundary of the State of São Paulo. 1: 100,000 (UTM projection), WGS Datum 1984. Elaborated by Luís Campanha, modified by Lilian P. Faria Pereira. 
DNA extraction, PCR and Sequencing. Total genomic DNA was extracted following the protocol of saline extraction method (Aljanabi, Martinez, 1997). Partial sequences of the cytochrome $\mathrm{c}$ oxidase 1 (COI or Cox 1 ) gene have been amplified by the polymerase chain reaction $(\mathrm{PCR})$ using the universal primers FishF1 (5 ' - TCA ACC AAC CAC AAA GAC ATT GGC AC-3 ') and FishR1 (5 ' - TAG ACT TCT GGG TGG CCA AAG AAT CA-3') (Ward et al., 2005). PCR was conducted for final volume of $50 \mu \mathrm{L}$ containing $1 \mathrm{x}$ buffer solution, $0.2 \mathrm{mM}$ of each DNTP, $25 \mathrm{mM} \mathrm{MgCl}, 0.2 \mu \mathrm{M}$ of each primer (sense and anti-sense), 1.0 U of Platinum Taq DNA Polymerase High Fidelity (Invitrogen ${ }^{\mathrm{TM}}$, Carlsbad, CA, USA) and $0.5-2 \mathrm{ng}$ of DNA. The amplification reaction was conducted in a PTC-200 thermal cycler (MJ Research, Waltham, MA, USA) with an initial cycle of denaturation at $94^{\circ} \mathrm{C}$ for $2 \mathrm{~min}$, followed by 35 cycles $\left(94^{\circ} \mathrm{C}\right.$ for $40 \mathrm{~S}, 58^{\circ} \mathrm{C}$ for $1 \mathrm{~min}, 72^{\circ} \mathrm{C}$ for $1 \mathrm{~min}$ ), and the final extension at $72^{\circ} \mathrm{C}$ for $7 \mathrm{~min}$.

PCR products were purified with CleanSweep ${ }^{\mathrm{TM}}$ PCR Purification Reagent (Applied Biosystems ${ }^{\mathrm{TM}}$ ), according to the protocol provided by the manufacturer. For the sequencing reactions the BigDye ${ }^{\mathrm{TM}}$ Terminator v3.1 Cycle Sequencing Kit (Applied Biosystems TM) was used. Sequencing was performed on the ABI 3730 DNA Analyzer (Applied Biosystems ${ }^{\mathrm{TM}}$ ).

Sequence Analysis. The COI partial sequences of all samples were edited in the Chromas V.2.6 program. The Codon Code Aligner V 1.5.2 program (Codon Code Corporation, Dedham, Massachusetts, United States) was used for quality evaluation and obtaining the consensus sequence (contig) from the forward and reverse sequences.

The sequences were compared to the sequences of other species of Gymnotus deposited in GenBank (Tab. S1) for the identification of similarity using the MegaBLAST program (Zhang et al., 2000; Morgulis et al., 2008). The number of haplotypes of the partial sequences of the COI gene was determined in the DnaSP program V.5.10 (Rozas et al., 2003). Sequences from each haplotype were deposited in GenBank (http://www. ncbi.nlm.nih.gov) (accession numbers: MN167125, MN167126, MN167127, MN167128, MN167129, MN167130, MN167131).

The sequences were aligned with the ClustalW command (Thompson et al., 1994) implemented in the MEGA 6 program (Tamura et al., 2014). Neighbor-Joining (NJ) based on Kimura two Parameter (K2P) genetic distance were used to analyze the phenetic relationship between the samples, as recommended by Barcode of Life. The bootstrap re-sampling analysis was performed using 1,000 replicates (Nei, Kumar, 2000) and the genetic divergence was calculated by the K2P distances (Kimura, 1980).
PCR-RFLP. Gymnotus partial COI sequences amplified herein, and those retrieved from GenBank were assessed using the NEBCutter program (Vincze et al., 2003). The diagnostic enzymes were used to distinguish among the Gymnotu sampled individuals.

Digestion was carried out at $10 \mu \mathrm{L}$ final volume, including $1.0 \mu \mathrm{L}$ of endonuclease (10 U.mL-1) (BioLabs), $1 \mu \mathrm{L}$ of 10x NEBuffer 4 (50mM Potassium Acetate, $20 \mathrm{mM}$ Tris-acetate, $10 \mathrm{mM}$ Magnesium Acetate, $1 \mathrm{mM}$ dithiothreitol (DTT), $\mathrm{pH} 7.9,25^{\circ} \mathrm{C}$; Biolabs) and $5 \mu \mathrm{L}$ of the PCR product. Solutions were incubated for $1-2 \mathrm{~h}$ at $37^{\circ} \mathrm{C}$ in the thermal block. The resulting sizes of restriction fragments were determined in 3.0\% agarose gel electrophoresis by comparison with a standard DNA molecular weight marker. Images were digitalized for further analysis of the banding patterns.

\section{Results}

Molecular Identification. Out of 64 sequences examined only two showed poor quality and could not be used. After editing, the sequences were 585 bp long. Of the 62 successfully sequenced samples, 59 showed similarity of 99 to $100 \%$ with the species G. sylvius Albert \& Fernandes-Matioli, 1999 and the other three sequences presented a best identity with $G$. inaequilabiatus (Valenciennes, 1839) when compared with other GenBank sequences in the MegaBLAST program. However, a species level match was not made, presumably due to misidentifications of the species names in GenBank.

The bootstrap values indicate branch statistical supports. Analysis showed that specimens from the fishing in the Jacaré-Guaçu River grouped in two different clades: one with sequences of G. sylvius (clade A) and another one with sequences of $G$. inaequilabiatus (clade C) (Fig. 2). The first one comprising $95.2 \%$ of the individuals sampled and the second one $4.8 \%$. Specimens grouped in clade A yielded 5 haplotypes (Photos S2, S3, $\mathbf{S 4}, \mathbf{S 5}$ and $\mathbf{S 6})$ with 4 polymorphic sites $(\mathrm{n}=59)$ and in clade C, 2 haplotypes (S7 and S8) with 3 polymorphic sites $(n=3)$.

Considering a recent revision of Craig et al. (2017) with the description of seven subspecies of $G$. carapo Linnaeus, 1758, and a revision of Craig et al. (2018) of G. carapo and G. tigre Albert \& Crampton, 2003 clade we preliminary identified here two species: $G$. cf. sylvius and G. cf. cuia Craig, Malabarba, Crampton \& Albert, 2018. Species of $G$. cf. sylvius were collected in the four fishing sites and G. cf. cuia in A2, A3 and A4.

The intraspecific genetic divergence for $G$. cf. sylvius ranged from 0.0 to $0.6 \%$ and for $G$. cf. cuia from 0.0 to $0.9 \%$. The divergence between $G$. cf. sylvius and G. cf. cuia ranged from 4.7 to $5.6 \%$ (Tab. 1). 


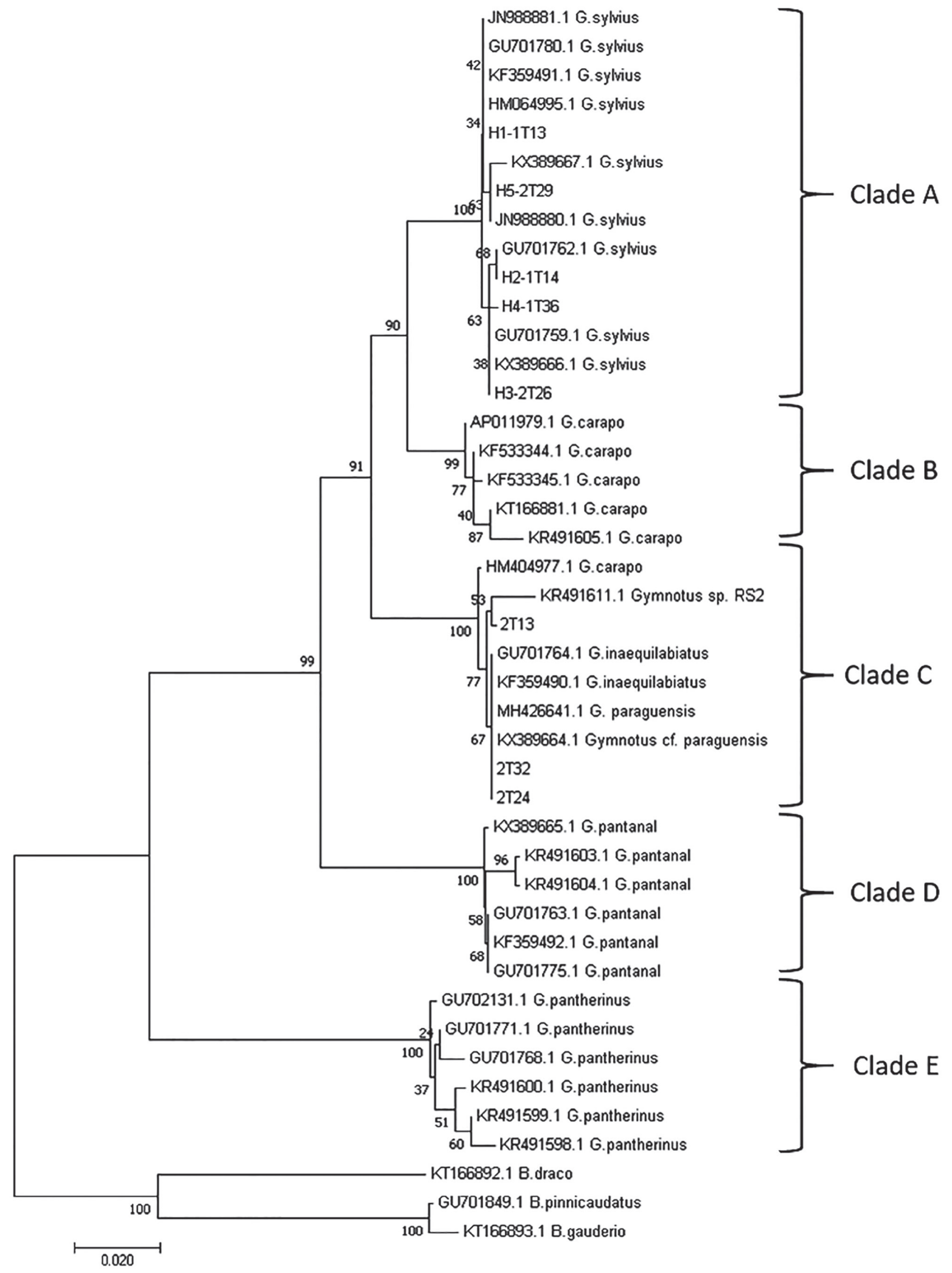

Fig. 2. Neighbor-joining dendrogram of the COI partial sequences of Gymnotus spp. (1T13, 2T29, 1T14, 1T36, 2T26, 2T13, $2 \mathrm{~T} 32$ and 2T24) collected in the Jacaré-Guaçu River, State of São Paulo, and obtained from GenBank, constructed from the distances of Kimura (K2P). The bootstrap values are indicated on the branches. 
PCR-RFLP. Based on the in silico analysis, we determined the enzymes that can be used for the diagnosis of the Gymnotus species present in the Jacaré-Guaçu River. The enzymes that allowed differentiation between the species were NlaIII ( $5^{\prime}$.... CATG' ... 3') and $\operatorname{SacI}\left(5^{\prime}\right.$... GAGCT'C ... $\left.3^{\prime}\right)$. These two enzymes generated fragments that allowed also to differentiate the species $G$. pantanal Fernandes, Albert, Daniel-Silva, Lopes, Crampton \& Almeida-Toledo, 2005 and G. pantherinus (Steindachner, 1908), in places where these two species occur in sympatry with $G$. cf. sylvius and G. cf. cuia (Tabs. 2-3).

COI cleavage patterns using NlaIII and SacI endonucleases are depicted in the Figs. 3-4.

Tab. 1. Genetic divergence by parameter K2P for the analyzed species.

\begin{tabular}{lccccc}
\hline & G. cf. sylvius & G. carapo & G. cf. cuia & G. pantanal & G. pantherinus \\
\hline G.cf. sylvius & $0.0-0.6 \%$ & $2.6-4,0 \%$ & $4.7-5.6 \%$ & $6.8-7.1 \%$ & $13.0-14.8 \%$ \\
G. carapo & - & $0.3-1.5 \%$ & $4.6-6.5 \%$ & $6.6-8.0 \%$ & $12.7-15.0 \%$ \\
G. cf. cuia & - & - & $0.0-0.9 \%$ & $7.2-8.4 \%$ & $14.8-17.7 \%$ \\
G. pantanal & - & - & - & $0.0-1.0 \%$ & $13.1-15,8 \%$ \\
G. pantherinus & - & - & - & - & $0.2-1.6 \%$ \\
\hline
\end{tabular}

Tab. 2. Size of fragments generated by NlaIII for $G$. cf. sylvius, G. cf. cuia, G. pantherinus and G. pantanal.

\begin{tabular}{ccccc}
\hline Fragments & G. cf. sylvius & G. cf. cuia & G. pantherinus & G. pantanal \\
\hline 1 & 306 & 189 & 97 & 306 \\
2 & 382 & 193 & 591 & 382 \\
3 & & 306 & & \\
\hline
\end{tabular}

Tab. 3. Size of fragments generated by SacI for G. cf. sylvius, G. cf. cuia, G. pantherinus and G. pantanal.

\begin{tabular}{ccccc}
\hline Fragments & G. cf. sylvius & G. cf. cuia & G. pantherinus & G. pantanal \\
\hline 1 & 234 & 160 & Does not cut & Does not cut \\
2 & 454 & 528 & & \\
\hline
\end{tabular}

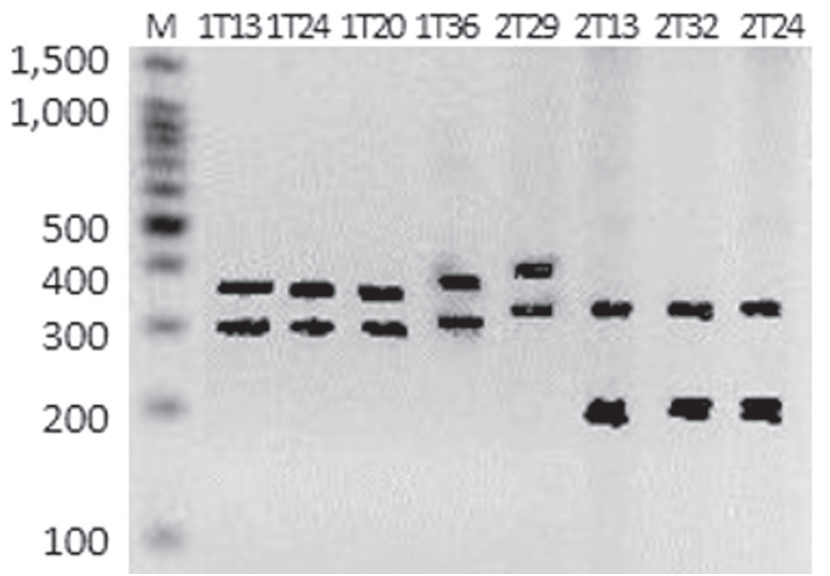

Fig. 3. Agarose gel electrophoresis $(3.0 \%)$ of NlaIII restriction fragments obtained from COI partial PCR amplification. Gymnotus cf. sylvius (1T13, 1T24, 1T20, 1T36, 2T29) and G. cf. cuia (2T13, 2T32 and 2T24). M$100 \mathrm{bp}$ molecular weight marker (Sinapse Inc). Numbers at fragments indicate estimated molecular weight.
M 1T13 1T24 1T20 1T36 2T292T131T36 2T26 2T32 2T24

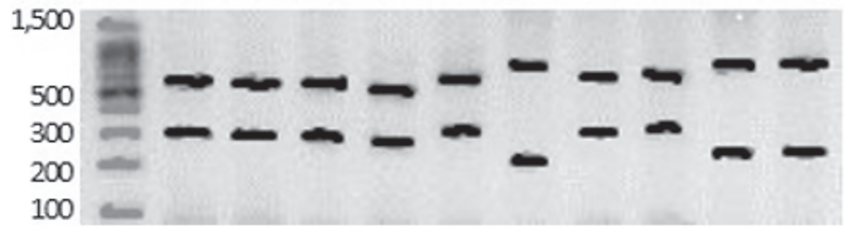

Fig. 4. Agarose gel electrophoresis $(3.0 \%)$ of NlaIII restriction fragments obtained from COI partial PCR amplification. Gymnotus cf. sylvius (1T13, 1T24, 1T20, 1T36, 2T26, 2T29) and G. cf. cuia (2T13, 2T32 and 2T24). M- 100 bp molecular weight marker (Sinapse Inc). Numbers at fragments indicate estimated molecular weight.

\section{Discussion}

Successful conservation plans need precise species identification (FAO, 2013). Thus, genetic markers have been applied widely for traceability of fish and fish product as well as for the species identification and populations to enforce fisheries regulation for the conservation of fisheries resources (Ogden, 2008). Partial sequences of COI obtained in this study demonstrated that the Gymnotus species caught as live bait by artisanal fisher community in the JacaréGuaçu River belong to two distinct species - G. cf. sylvius and $G$. cf. cuia.

Species of Gymnotus known to occur in the Upper Paraná basin include: G. carapo australis Craig, Crampton \& Albert, 2017, G. cuia, G. inaequilabiatus, G. pantanal, G. pantherinus, G. paraguensis Albert \& Crampton, 2003 and G. sylvius (Craig et al., 2017; Craig et al., 2018). Of these species, G. carapo australis, G. cuia, and G. pantanal are ecologically abundant and $G$. inaequilabiatus, $G$. pantherinus, G. paraguensis and G. sylvius are not abundant. Gymnotus inaequilabiatus is often misidentified or mistaken for other species, despite the presence of multiple salient external diagnostic characters (Maxime, Albert, 2014) that place it in the G. tigre clade rather than the G. carapo clade. Further, G. inaequilabiatus is unique among congeners in its large adult body size, growing to one-meter total length.

We found inconsistent taxonomic identifications when comparing the sequences of the specimens classified here as $G$. cf. sylvius and $G$. cf. cuia with the sequences available in GenBank. Three sequences presented better identity with $G$. inaequilabiatus (clade C), but also grouped with $G$. paraguensis, G. cf. paraguensis, G. carapo and Gymnotus sp. (Fig. 2). Our sequences of G. cf. cuia presented also $99 \%$ of identity with Gymnotus new sp. RS2 that, according to Tagliacollo et al. (2016), belongs to G. carapo clade and not to $G$. tigre clade, which includes the species $G$. inaequilabiatus and G. paraguensis (Maxime, Albert, 2014; Craig et al., 2018). It is possible that the specimens identified as $G$. inaequilabiatus in previous studies based on Graça, Pavanelli (2007) and Ota et al. (2018) may be actually $G$. cuia. These discordances were probably caused by misidentification of specimens used in previous studies, 
once new data from literature, as the recent revisions of Scacchetti et al. (2011), Craig et al. (2017, 2018) and Utsunomia et al. (2018) are now available to elucidate this complex group.

Despite of these considerations, we demonstrated that at least two different species are fished as live bait in JacaréGuaçu River. These two species, preliminarily identified here as G. cf. sylvius and G. cf. cuia, presented $4.7 \%$ to $5.6 \%$ of genetic divergence (Tab. 1) and they can easily be discriminated by PCR-RFLP method developed in this work. This technique has been proven to efficiently identify different taxa for distinct purposes (Wolf et al., 1999; Bieliková et al., 2010; Schmidt et al., 2015). The PCR-RFLP technique developed herein showed that the NlaIII and SacI endonucleases cut patterns clearly distinguished $G$. pantanal and $G$. pantherinus species where they occur in sympatry with $G$. cf. sylvius and G. cf. cuia, as shown in Tabs. 2 - 3 . The data demonstrated that the most frequent species was $G$. cf. sylvius corresponding to $95.2 \%$ of the fished specimens. Fernandes-Matioli et al. (2000) also observed Gymnotus populations of different species living in sympatry in some watersheds of Southeastern Brazil and always one of the species occur at a significantly lower frequency. The sequences alignment and analysis of the haplotypes retrieved from GenBank database allowed a carefully examination of polymorphic restriction sites to detect variation among species, excluding sites with intra-specific variation.

The identification of Gymnotus species fished for live bait is extremely important for the management of this fishery resource and as a result to determine proper fisheries regulation. The current fishing legislation in the Paraná River Basin refers to Gymnotus species as G. carapo and determines the minimum capture size of $20 \mathrm{~mm}$ (IBAMA, 2009). Thus, the present outcomes show the need for legislation change to include other Gymnotus being caught as live bait. The minimum capture size depends on the captured species, since each species has its reproduction cycle. Sousa et al. (2017) also suggested a revision of capture legislation in the Pantanal of Mato Grosso do Sul, because it recognizes two Gymnotus species. However, these authors found three species of Gymnotus commercialized as live bait in the region.

The use of live bait has been concerning worldwide due to risks of introduction of invasive alien species by sport anglers and the ecological impact on the native biodiversity once this live bait species become established (Sá et al., 2017). At the same time, even local fish species being indiscriminately used as live bait can impact the long-term survival of local species population. Species identification and management through legal monitoring is central to maintain sustainable fishing by local communities. The molecular surveillance tool developed herein allows the implementation of a rapid and low-cost diagnostic system by PCR-RFLP to identify Gymnotus species in the sampling fishing area of this study, which can be applied to yield seasonal Gymnotus fishing data and support a reliable fishing regulation to use this fisheries resources sustainably.

\section{Acknowledgments}

We gratefully acknowledge the fishing community of Fazenda São Giacomo and the Jacaré-Guaçu River, Ibitinga, SP in contributing to this work. The team of the Laboratório de Genética de Organismos Aquáticos e Aquicultura (Lagoaa) at the Universidade de Mogi das Cruzes (UMC) and Fundação de Apoio a Ensino e Pesquisa (FAEP) for the support and assistance during the laboratory analyzes. Conselho Nacional de Desenvolvimento Científico e Tecnológico (CNPq) by the scholarship of Dr. Alexandre W. S. Hilsdorf. Dr. Luiz A. W. Peixoto and Dr. Michel D. Gianeti from MZUSP, for help in identifying some specimens. Dr. Paula M. de Castro from Instituto de Pesca (IP), SP, for assisting in the planning of this work. Messrs. Luiz Evangelista and Sérgio Silva from IP, for assisting in field surveys.

\section{References}

Albert JS. Species diversity and phylogenetic systematics of American knifefishes (Gymnotiformes, Teleostei). Misc Publ Mus Zool Univ Mich. 2001; 190:1-127.

Albert JS, Crampton WGR. Seven new species of the Neotropical electric fish Gymnotus (Teleostei, Gymnotiformes) with a redescription of G. carapo (Linnaeus). Zootaxa. 2003; 287(1):1-54. http://dx.doi.org/10.11646/zootaxa.287.1.1

Aljanabi SM, Martinez I. Universal and rapid salt-extraction of high-quality genomic DNA for PCR-based techniques. Nucleic Acids Res. 1997; 25(22):4692-93. https://doi. org/10.1093/nar/25.22.4692

Alves-Gomes JA, Ortí G, Haygood M, Heiligenberg W, Meyer A. Phylogenetic analysis of the South American electric fishes (Order Gymnotiformes) and the evolution of their electrogenic system: A synthesis based on morphology, electrophysiology, and mitochondrial sequence data. Mol Biol Evol. 1995; 12(2):298-318. https://doi.org/10.1093/ oxfordjournals.molbev.a040204

Bieliková M, Pangallo D, Turňa J. Polymerase chain reaction - restriction fragment length polymorphism (PCR-RFLP) as a molecular discrimination tool for raw and heat-treated game and domestic animal meats. J Food Nutr Res. 2010; 49(3):134-39.

Craig JM, Crampton WGR, Albert JS. Revision of the polytypic electric fish Gymnotus carapo (Gymnotiformes, Teleostei), with descriptions of seven species. Zootaxa. 2017; 4318(3):401-38. http://dx.doi.org/10.11646/ zootaxa.4318.3.1

Craig JM, Malabarba LR, Crampton WGR, Albert JS. Revision of banded knifefishes of the Gymnotus carapo and G. tigre clades (Gymnotidae Gymnotiformes) from the Southern Neotropics. Zootaxa 2018; 4379(1):47-73. http://dx.doi. org/10.11646/zootaxa.4379.1.3

Drake DAR, Mandrak NE. Ecological risk of live bait fisheries: A new angle on selective fishing. Fisheries 2014; 39(5):20111. https://doi.org/10.1080/03632415.2014.903835 
Fernandes-Matioli FMC, Matioli SR, Almeida-Toledo LF. Species diversity and geographic distribution of Gymnotus (Pisces: Gymnotiformes) by nuclear (GGAC)n microsatellite analysis. Genet Mol Biol. 2000; 23(4): 803-07. http://dx.doi. org/10.1590/S1415-47572000000400016

Fernandes FMC, Albert JS, Daniel-Silva MFZ, Lopes CE, Crampton WGR, Almeida-Toledo LF. A new Gymnotus (Teleostei: Gymnotiformes: Gymnotidae) from the Pantanal Matogrossense of Brazil and adjacent drainages: Continued documentation of a cryptic fauna. Zootaxa. 2005; 933(1):1-14. http://dx.doi.org/10.11646/zootaxa.933.1.1

Food and Agriculture Organization (FAO). Fish identification tools for biodiversity and fisheries assessments: Review and guidance for decision-makers. Rome: Food and Agriculture Organization of the United Nations [Internet]. Rome; 2013. Available from: http://www.fao.org/docrep/019/i3354e/i3354e.pdf

Graça WJ, Pavanelli CS. Peixes da planície de inundação do Alto rio Paraná e áreas adjacentes. Maringá: EDUEM; 2007.

Hebert PDN, Cywinska A, Ball SL, deWaard JR. Biological identifications through DNA barcodes. Proc R Soc B. 2003; 270(1512):313-21. https://doi.org/10.1098/rspb.2002.2218

Hilsdorf AWS, Hallerman EM. Genetic resources of Neotropical fishes. Cham, Switzerland: Springer International Publishing AG; 2017.

Instituto Brasileiro do MeioAmbiente(IBAMA). Instrução Normativa IBAMA nº 26, de 2 de Setembro de 2009. Brasília: Diário Oficial da União; 2009. Available from: http://www.icmbio.gov.br/ cepsul/images/stories/legislacao/Instrucao_normativa/2009/ in_ibama_26_2009_normaspescabaciahidrografica_rioparana rev_in_30_2005.pdf

Kimura M. A simple method for estimating evolutionary rate of base substitutions through comparative studies of nucleotide sequences. J Mol Evol. 1980; 16(2):111-20.

Margarido VP, Bellafronte E, Moreira-Filho O. Cytogenetic analysis of three sympatric Gymnotus (Gymnotiformes, Gymnotidae) species verifies invasive species in the Upper Paraná River basin, Brazil. J Fish Biol. 2007; 70(sb):155-64. https://doi.org/10.1111/j.1095-8649.2007.01365.x

Maxime EL, Albert JS. A new species of Gymnotus (Gymnotiformes: Gymnotidae) from the Fitzcarrald Arch of southeastern Peru. Neotrop Ichthyol. 2009; 7(4):579-85. http:// dx.doi.org/10.1590/S1679-62252009000400004

Maxime EL, Albert JS. Redescription of the Tuvirão, Gymnotus inaequilabiatus Valenciennes, 1839, using high-resolution x-ray computed tomography. Copeia. 2014; 2014(3):462-72. https://doi.org/10.1643/CI-13-054

Milhomem SSR, Crampton WGR, Pieczarka JC, Shetka GH. Silva DS, Nagamachi CY. Gymnotus capanema, a new species of electric knife fish (Gymnotiformes, Gymnotidae) from eastern Amazonia, with comments on an unusual karyotype. J Fish Biol. 2012; 80(4):802-15. https://doi.org/10.1111/ j.1095-8649.2012.03219.x

Morgulis A, Coulouris G, Raytselis Y, Madden TL, Agarwala R, Schäffer AA. Database indexing for production MegaBLAST searches. Bioinformatics 2008; 24(16):1757-64. https://doi. org/10.1093/bioinformatics/btn322
Nei M, Kumar S. Molecular evolution and phylogenetics. New York: Oxford University Press; 2000.

Ogden R. Fisheries forensics: The use of DNA tools for improving compliance, traceability and enforcement in the fishing industry. Fish Fish. 2008; 9(4):462-72. https://doi.org/10.1111/ j.1467-2979.2008.00305.x

Ota RR, Deprá GC, Graça WJ, Pavanelli, CS. Peixes da planície de inundação do alto rio Paraná e áreas adjacentes: revised, annotated and updated. Neotrop Ichthyol. 2018; 16(2):e170094. https://doi.10.1590/1982-0224-20170094

Rozas J, Sánchez-DelBarrio JC, Messeguer X, Rozas R. DnaSP, DNA polymorphism analyses by the coalescent and other methods. Bioinformatics 2003; 19(18):2496-97. https://doi. org/10.1093/bioinformatics/btg359

Sá E, Costa PF, Fonseca LC, Alves AS, Castro N, Cabral SS, Chainho P, Canning-Clode J, Melo P, Pombo AM, Costa JL. Trade of live bait in Portugal and risks of introduction of nonindigenous species associated to importation. Ocean Coast Manage. 2017; 146:121-28. https://doi.org/10.1016/j. ocecoaman.2017.06.016

Scacchetti PC, Pansonato-Alves JC, Utsunomia R, Oliveira C, Foresti F. Karyotypic diversity in four species of the genus Gymnotus Linnaeus, 1758 (Teleostei, Gymnotiformes, Gymnotidae): Physical mapping of ribosomal genes and telomeric sequences. Comp Cytogenet. 2011; 5(3):223-35. https://doi.org/10.3897/compcytogen.v5i3.1375

Schmidt BF, Amorim AF, Hilsdorf AWS. PCR-RFLP analysis to identify four ray species of the genus Dasyatis (Elasmobranchii, Dasyatidae) fished along the southeastern and southern coast of Brazil. Fish Res. 2015; 167:71-74. https://doi.org/10.1016/j. fishres.2014.12.025

Sousa TP, Marques DKS, Vitorino CA, Faria KC, Braga GSF, Ferreira DC, Venere PC. Cytogenetic and molecular data support the occurrence of three Gymnotus Species (Gymnotiformes: Gymnotidae) used as live bait in Corumbá, Brazil: implications for conservation and management of professional fishing. Zebrafish. 2017; 14(2):177-86. https:// doi.org/10.1089/zeb.2016.1356

Tagliacollo VA, Bernt MJ, Craig JM, Oliveira C, Albert JS. Model-based total evidence phylogeny of Neotropical electric knifefishes (Teleostei, Gymnotiformes). Mol Phylogenet Evol. 2016; 95:20-33. https://doi.org/10.1016/j.ympev.2015.11.007

Tamura K, Stecher G, Peterson D, Filipski A, Kumar S. MEGA6: Molecular Evolutionary Genetics Analysis version 6.0. Mol Biol Evol. 2014; 30(12):2725-29. https://doi.org/10.1093/ molbev/mst197

Thompson JD, Higgins DG, Gibson TJ. CLUSTAL W: Improving the sensitivity of progressive multiple sequence alignment through sequence weighting, position-specific gap penalties and weight matrix choice. Nucleic Acids Res. 1994; 22(22):467380. https://doi.org/10.1093/nar/22.22.4673

Utsunomia R, Melo S, Scacchetti PC, Oliveira C, Machado MA, Pieczarka JC. Particular chromosomal distribution of microsatellites in five species of the Genus Gymnotus (Teleostei, Gymnotiformes). Zebrafish. 2018; 15(4):398-403. https://doi.org/10.1089/zeb.2018.1570 
Vincze T, Posfai J, Roberts RJ. NEBcutter: A program to cleave DNA with restriction enzymes. Nucleic Acids Res. 2003; 31(13):3688-91. https://doi.org/10.1093/nar/gkg526

Ward RD, Zemlak TS, Innes BH, Last PR, Hebert PDN. DNA barcoding Australia's fish species. Philos Trans R Soc London B. 2005; 360(1462):1847-57. https://doi. org/10.1098/rstb.2005.1716

Wolf C, Rentsch J, Hübner P. PCR-RFLP Analysis of mitochondrial DNA: A reliable method for species identification. J Agric Food Chem. 1999; 47(4):1350-55. https://doi.org/10.1021/j99808426
Zhang Z, Schwartz S, Wagner L, Miller W. A greedy algorithm for aligning DNA sequences. J Comput Biol. 2000; 7(1-2):203-14. https://doi.org/10.1089/10665270050081478

Submitted July 22, 2019

Accepted October 17, 2019 by Claudio Oliveira 